\title{
APLIKASI PENGOLAHAN DATA OBAT PADA KLINIK HADI WIJAYA KOTA METRO
}

\author{
Rizki Amelia ${ }^{(1)}$ Dedi Irawan ${ }^{(2)}$ \\ Jurusan Ilmu Komputer, Fakultas Ilmu Komputer,Universitas Muhammadiyah Metro \\ Jl.Gatot Subroto No.100 Yosodadi Kota Metro, Telpon :(0725)42445-Fax(0725)42454 \\ E-mail: dedi.mti@gmail.com
}

\begin{abstract}
Abstrak
Tugas akhir ini merupakan hasil dari analisis terhadap pengolahan data obat yang sedang berjalan dan hasil dari aplikasi pengolahan data obat pada Klinik Hadi Wijaya Kota Metro.

Keadaan pada pengolahan data obat di Klinik Hadi Wijaya Kota Metro masih dicatat menggunakan buku besar dalam pendataan obat. Sulitnya pencarian data obat dalam pendataan stok karena banyaknya jumlah obat yang dicatat di buku besar sehingga terkesan lama dalam mencari obat. Tidak diketahuinya stok obat yang tersedia sehingga dalam pelayanan sering terjadi kelangkaan obat karena obat telah habis. Proses pembuatan laporan kebutuhan obat yang akan dilaporkan ke kepala klinik serta ke PBF (Pedagang Besar Farmasi) dan Apotik kurang efektif. Dalam penelitian menggunakan metode berupa pengamatan, wawancara, dokumentasi dan studi pustaka. Sedangkan Program yang dibuat menggunakan bahasa pemograman Java Development Kit (JDK), aplikasi NetBeans IDE 8.0.2 dengan database Mysql. Berdasarkan hasil penelitian, hasil aplikasi pengolahan data obat mampu mengatasi permasalahan yang di hadapi oleh petugas asisten apoteker pada Klinik Hadi Wijaya Kota Metro. Dengan adanya aplikasi pengolahan data obat dengan bahasa pemograman Java Development Kit (JDK) dapat membantu petugas asisten apoteker pada Klinik Hadi Wijaya Kota Metro dalam mengelola data obat menjadi lebih mudah dan lebih efektif. Dengan adanya aplikasi pengolahan data obat Klinik Hadi Wijaya Kota Metro dapat mempermudah dalam proses pencarian data obat maupun pembuatan data laporan obat.
\end{abstract}

Kata Kunci: Aplikasi Pengolahan Data Obat, Laporan Data Obat dan Stok Obat.

\section{PENDAHULUAN}

Perkembangan ilmu pengetahuan dan teknologi yang semakin pesat dan canggih, maka kebutuhan akan suatu informasi menjadi sangat penting bagi masyarakat luas. Dimana informasi yang dihasilkan diharapkan dapat dikelola dengan mudah, cepat dan dapat dipercaya kebenarannya. Dengan perkembangan tersebut, maka proses pengelolaan sistem informasi melalui sistem komputerisasi mampu menghasilkan kinerja yang lebih baik. Hal tersebut dipengaruhi oleh kecepatan, ketepatan maupun keamanan suatu informasi yang dikelola melalui sistem komputerisasi sehingga mampu bekerja dengan baik. Saat ini peran informasi sangat penting dalam menunjang berbagai kegiatan khususnya peran informasi dalam dunia pendidikan. Dalam menyajikan informasi yang aktual dan akurat, peran komputer sangat mutlak dibutuhkan. 
Kebutuhan akan peningkatan kecepatan dan ketepatan dalam pengolahan data semakin mendesak setiap kalangan agar mampu bersaing dalam peningkatan kuantitas maupun kualitas pelayanan yang diberikan. Kemajuan teknologi semakin meningkat terutama dalam bidang komputer. Kehadiran pengolah data dalam masa sekarang ini banyak membawa perubahan, baik dalam dunia usaha, instansi-instansi pemerintah, swasta, maupun bidang-bidang lainnya baik dalam pengolahan data maupun keakuratan data yang dihasilkan. Klinik Hadi Wijaya berdiri pada tanggal 05 April 2013 yang beralamat di Jl.Diponegoro 22 Hadimulyo Timur Metro Pusat, sebelum klinik berdiri pelayanan kesehatan ini dinamakan balai pengobatan (bp) yang beralamatkan di Jl.Raden Imba Kesuma no 40 Kota Metro yang didirikan oleh dr.Hariyadi. klinik Hadi Wijaya ditetapkan izin menurut peraturan undang-undang nomer 36 tahun 2009 tentang kesehatan dan peraturan menteri kesehatan nomor 028/MENKES/PER/I/2011 tentang klinik. Pada tahun 2013 Klinik Hadi Wijaya sudah melayani pasien rawat inap namun tidak dapat melayani pasien yang menggunakan fasilitas bpjs, askes, kis dan lainnya karena belum bekerjasama dengan pelayanan bpjs, tahun 2016 berhenti bekerjasama dengan BPJS. Pada tahun 2017 sampai sekarang pelayanan kesehatan menggunakan fasilitas umum. Sebagaimana firman Allah tentang kesehatan yang tertuang dalam ayat suci (QS. Asy-Syu'ara : yang berbunyi:

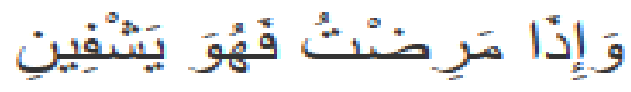

Artinya : "dan apabila aku sakit, Dialah Yang menyembuhkan aku" (QS. AsySyu'ara : 80)

Pengolahan data obat di Klinik Hadi Wijaya Kota Metro masih dicatat menggunakan buku besar dalam pendataan obat. Sulitnya pencarian data obat dalam pendataan stok karena banyaknya jumlah obat yang dicatat di buku besar sehingga terkesan lama dalam mencari obat. Tidak diketahuinya stok obat yang tersedia sehingga dalam pelayanan sering terjadi kelangkaan obat karena obat telah habis. Proses pembuatan laporan kebutuhan obat yang akan dilaporkan ke kepala klinik serta ke PBF (Pedagang Besar Farmasi) dan Apotik kurang efektif. Dengan mempertimbangkan permasalahan di atas, penulis tertarik untuk merancang sebuah aplikasi pengolahan data obat pada Klinik Hadi Wijaya Kota Metro, dalam bentuk Tugas Akhir yang berjudul "APLIKASI PENGOLAHAN DATA OBAT PADA KLINIK HADI WIJAYA KOTA METRO".

\section{KAJIAN PUSTAKA DAN LANDASAN TEORI}

\subsection{Definisi Perancangan}

Berikut ini penjelasan dari ahli tentang definisi perancangan yaitu:

Definisi perancangan menurut Al-Bahra Bin Ladjamudin yang dikutip oleh Sofyan (2015:37) (dkk), menyebutkan bahwa:

Perancangan adalah suatu kegiatan yang memiliki tujuan untuk mendesign sistem baru yang dapat menyelesaikan masalahmasalah yang dihadapi perusahaan yang diperoleh dari pemilihan alternatif sistem yang terbaik. Berdasarkan definisi Perancangan tersebut, dapat disimpulkan bahwa perancangan merupakan suatu alternatif untuk memecahkan masalah dan yang dipilih selama tahap analisis dalam pemecahan masalah yang dihadapi perusahaan.

\subsection{Definisi Aplikasi}

Berikut ini merupakan penjelasan dari para ahli tentang definisi aplikasi yaitu:

Menurut Jogiyanto (1999:12) yang dikutip oleh Afrizal (2014:3), menyebutkan bahwa "Aplikasi adalah program yang memiliki aktivitas pemrosesan perintah yang 
diperlukan untuk melaksanakan permintaan pengguna dengan tujuan tertentu”. Menurut Janner (2006:22) yang dikutip oleh Afrizal (2014:3), menyebutkan bahwa "aplikasi adalah program atau sekelompok program yang dirancang untuk digunakan oleh pengguna akhir (end user)".

Berdasarkan definisi para ahli diatas maka dapat diambil kesimpulan bahwa aplikasi adalah program yang siap digunakan yang dibuat untuk melakukan aktivitas atau pekerjaan tertentu yang saling terkait sehinga dapat memproses input menjadi output.

\subsection{Definisi Data}

Data dapat dikatakan sebagai sesuatu yang belum mempunyai arti bagi penerimanya dan masih memerlukan adanya suatu pengolahan. Data bisa berwujud suatu keadaan, gambar, huruf, angka, matematika, bahasa atau simbol-simbol lainnya yang bisa kita gunakan sebagai bahan untuk melihat lingkungan, objek, kejadian ataupun suatu konsep. Menurut McFadden et al (1999) yang dikutip Adi Nugroho (2011:5) "Data adalah fakta-fakta tentang segala sesuatu di dunia nyata yang dapat direkam dan disimpan pada media komputer". Berdasarkan diatas maka dapat diambil kesimpulan bahwa data adalah suatu bahan mentah dari sebuah fakta yang terjadi, bisa berupa angka, benda, kejadian, yang belum diolah pemakai belum memiliki arti atau informasi apapun bagi penerimanya. Berdasarkan definisi diatas maka dapat disimpulkan bahwa pengolahan data adalah perubahan bentuk data menjadi informasi kemudian proses operasi sistematis terhadap data. Operasi yang dilakukan dalam pengolahan data antara lain:

Masukan data (Input)

Tahap ini yang merupakan proses memasukan data kedalam proses komputer melalui alat input (input device)

Proses (processing)
Tahap ini yang merupakan proses pengolahan/pemrosesan dari data yang sudah dimasukan yang dilakukan oleh alat pemroses yang dapat berupa proses menghitung, membanding, mengklasifikasikan, mengurutkan dan mengendalikan.

Keluaran (output)

Tahap ini merupakan proses yang menghasilkan output dari hasil pengolahan data ke alat output (output device), yaitu berupa informasi. .

Seperti pada gambar 2.1 dibawah ini menurut Sutarman (Pengantar Teknologi Informasi 2009:4).

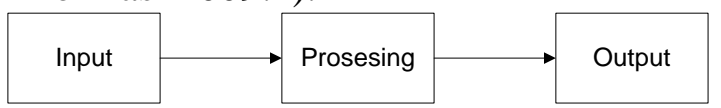

Gambar 2.1 Siklus Pengolahan Data

(Sumber: Penulis Tahun 2018)

\subsection{Definisi Klinik}

Irawati (2) (dkk) menarik kesimpulan sebagai berikut:

Klinik adalah suatu fasilitas kesehatan publik kecil yang didirikan untuk memberikan perawatan kepada pasien. Biasanya klinik bukan hanya mengobati penyakit-penyakit ringan seperti demam dan sebagainya, tetapi juga melayani pasien rawat jalan dan pasien rawat inap. Sedangkan kasus-kasus yang lebih parah diajukan ke rumah sakit. Klinik sesuai fungsi sosialnya, tetap diminta untuk menempatkan sekian persen berobat rawat inap.

\subsection{Bahasa Pemrograman}

Sejarah Java

Menurut Utomo (2013:4) Java pertama kali lahir dari The Green Project yang telah berjalan selama 18 bulan, dimulai awal tahun 1991 sampai tahun 1992. Project tersebut dimotori oleh Patrick Naughton, Mike Sheridan, James Gosling, dan Bill Joy, beserta sembilan programmer lainnya dari 
Sun Microsystems. Salah satu hasil project ini adalah maskot Duke yang dibuat oleh Joe Palrang. Pada perkembangan selanjutnya, project ini diberi nama Oak, diambil dari nama pohon yang tumbuh di depan jendela ruangan kerja James Gosling. Selanjutnya nama Oak ini tidak dipakai lagi karena sudah ada perangkat lunak lain yang telah terdaftar dengan menggunakan nama yang sama. Sebagai pengganti digunakan nama "Java" yang diambil dari nama kopi murni yang menjadi kesukaan Gosling. Sekitar bulan Maret 1995, pertama kali kode sumber Java versi 1.0a2 dibuka. Pada tahun 1995, Java pertama kali diluncurkan sebagai bahasa pemrograman umum (general purpose programming language) yang bisa dijalankan di web browser sebagai applet. Para pengembang bahasa Java menginginkan agar bahasa yang mereka buat nantinya dapat terintegrasi dengan pirantipiranti yang ada (small embedded customer device) sehingga dapat berkomunikasi satu sama lain. Sun Microsystem pun kemudian membuat sebuah JVM (Java Virtual Machine) yang diimplementasikan dalam bentuk JRE (Java Runtime Environment). JVM menjadi lingkungan tempat eksekusi program Java berlangsung sehingga objek yang ada dapat saling berinteraksi satu sama lain.

Tampilan logo java dapat dilihat pada gambar 2.2.

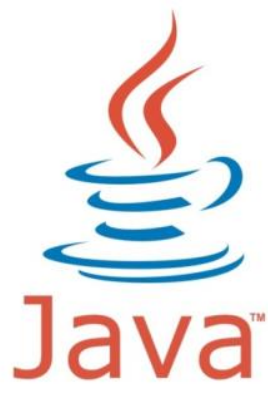

Gambar 2.2 Logo Java (Sumber: Google)

\subsection{Definisi Java}

Menurut Hudaya (2015:1) Java adalah bahasa pemrograman yang fenomenal. Sebagian ahli mengklaim bahwa kelebihankelebihan pada bahasa pemrograman sebelumnya telah diadopsi oleh java. Dalam hal kepopuleran, menurut rilis TIOBE Index (www.index.com) tiap bulan, Java berada di peringkat dua besar (bergantian dengan $\mathrm{C}$ yang menjadi peringkat pertama) dalam tiga tahun terakhir. Java bisa digunakan pada berbagai keperluan. Pemrograman berbasis teks seperti pada Clipper atau FoxPro for DOS yang biasa kita temui di kasir-kasir minimarket bisa dilakukan dengan Java. Pemrograman berbasis GUI desktop seperti yang dikenal pada Visual Basic, Visual FoxPro, atau Delphi juga bisa dilakukan dengan Java. Pemrograman untuk peranti mikro seperti ponsel atau tablet PC mudah dilakukan dengan Java. Tidak ketinggalan, pemrograman web bisa menggunakan Java Server Pages (JSP) atau Servlet.

Java memiliki tiga edisi untuk berbagai keperluan diatas, yaitu:

Java 2 Standard Edition (J2SE) untuk pemrograman pada komputer dekstop;

Java 2 Microdevice Edition (J2ME) untuk pemrograman pada peranti mikro seeperti ponsel;

Java 2 Enterprise Edition (J2EE) untuk membangun multi-tier enterprise seperti Java Bean dan Servlet. Java adalah sumber terbuka (open source) sehingga program berikut kode sumber yang digunakan untuk pengembangan perangkat lunak bebas diunduh dan bebas dimodifikasi. Java juga mendukung fitur-fitur pengembangan perangkat lunak terbaru seperti objectoriented programming (OOP). Java memiliki tingkat keamanan yang lebih baik dari kebanyakan bahasa pemrograman lain.

\subsection{Komponen Java}

Berikut tiga komponen penting yang dimiliki Java menurut Andi (2012:2), yaitu: 
The Java Programming Language adalah bahasa pemrograman yang digunakan untuk menulis kode program dalam platform java. The Java Platform adalah lingkungan yang digunakan untuk menjalankan kode program yang telah ditulis pada bahasa pemrograman java. The Java Application Program Interface adalah suatu kumpulan kelas-kelas dalam java yang digunakan untuk mengembangkan perangkat lunak berbasis GUI, penyimpanan data, serta pemrograman jaringan.

\subsection{NetBeans IDE}

Menurut Afrizal (4) IDE NetBeans adalah sebuah lingkungan pengembangan, sebuah tools untuk programmer menulis, mengompilasi, mencari kesalahan dan menyebarkan program. IDE NetBeans ditulis dalam Java, namun dapat mendukung bahasa pemrograman lain. Terdapat banyak modul untuk memperluas IDE NetBeans. IDE NetBeans adalah sebuah produk bebas dengan tanpa batasan bagaimana digunakan. NetBeans mengacu pada dua hal, yakni platform untuk pengembangan desktop java, dan sebuah Integrated Development Environment (IDE) yang dibangun menggunakan platform NetBeans. Platform NetBeans memungkinkan aplikasi dibangun dari sekumpulan komponenkomponen perangkat lunak moduler yang disebut 'modul'. Sebuah modul adalah suatu arsisp Java(Java Archive) yang membuat kelaskelas Java untuk berinteraksi dengan NetBeans Open API dan file manifestasi yang mengidentifikasinya sebagai modul. Aplikasi yang dibangun dengan modulmodul dapat dikembangkan dengan menambahkan modul-modul baru. Karena modul dapat dikembangkan secara independen, aplikasi berbasis platform NetBeans dapat dengan mudah dikembangkan oleh pihak ketiga secara mudah dan powerful. Penggunaan aplikasi NetBeans akan memudahkan developer software untuk membuat kode program, mengcompile, dan menjalankan program. dapat dilihat pada Gambar 2.3.

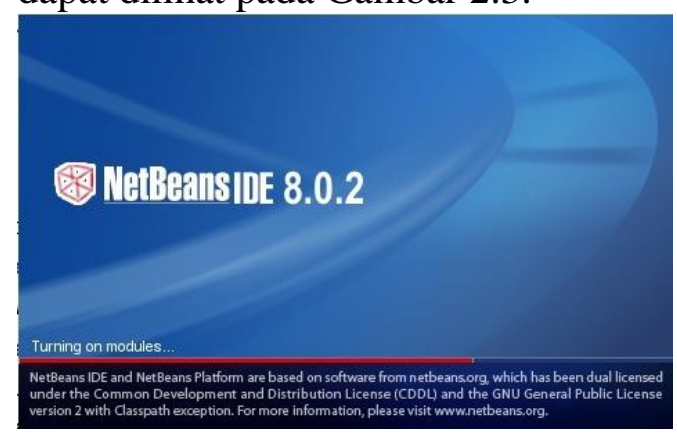

Gambar 2.3 Jendela Splashscreen NetBeans IDE 8.0.2

\subsection{Komponen GUI}

Pada aplikasi java, komponen GUI disimpan pada kontainer yang disebut form. Berikut komponen GUI pada Netbeans menurut Andi (2012:30) antara lain:

GUI Builder

GUI Builder merupakan jendela utama yang didalamnya terdapat komponen untuk merancang GUI. Terdiri dari design area, source area, propertis, palette, inspector.

Tampilan GUI Builder pada NetBeans IDE dapat dilihat pada Gambar 2.4.

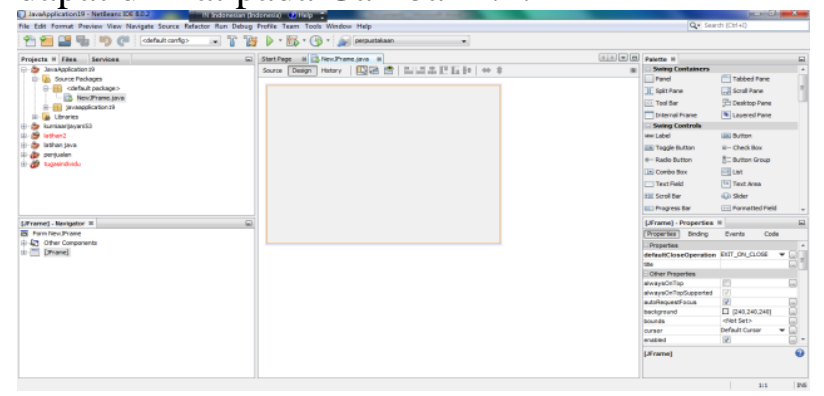

Gambar 2.4 Tampilan GUI Builder pada NetBeans IDE

(Sumber: Printscrean)

\subsection{Inspector Windows}

Inspector windows merupakan jendela yang menampilkan pohon pewarisan dari semua komponen form yang dibuka seperti button, label, timer dan sebagainya.

Tampilan jendela inspector dapat dilihat pada Gambar 2.5. 


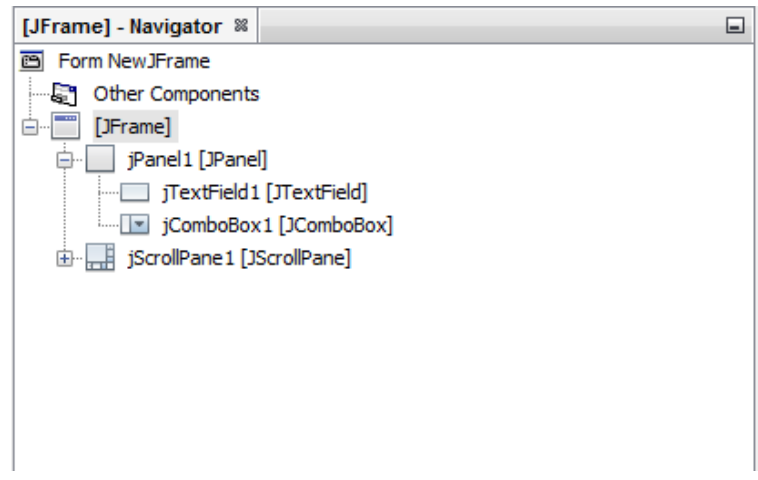

Gambar 2.5 Tampilan jendela inspector (Sumber: Printscrean)

\subsection{Palette Windows}

Palette windows merupakan jendela yang menampilkan daftar semua komponen swing yang dapat dimasukkan dalam form seperti label, button, menu, dan lainnya.

Tampilan jendela inspector dapat dilihat pada Gambar 2.6.

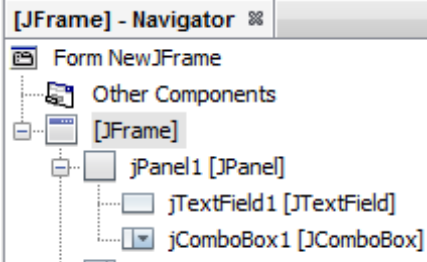

Gambar 2.6 Tampilan jendela inspector (Sumber: Printscrean)

\subsection{Design Area}

Design Area merupakan jendela yang digunakan untuk merancang antarmuka.

Tampilan Design Area dapat dilihat pada Gambar 2.7.

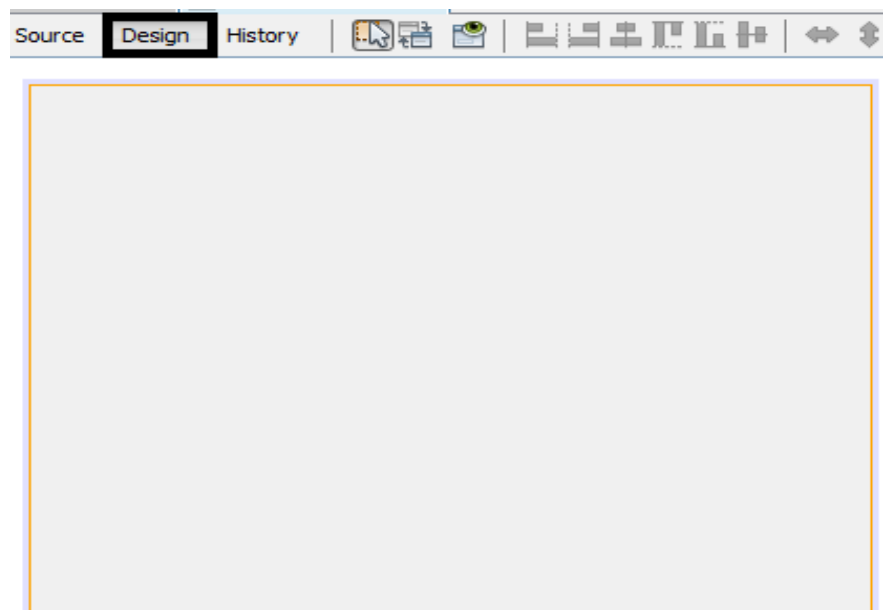

Gambar 2.7 Tampilan Design Area

(Sumber: Printscrean)

\subsection{Source Area}

Source Area merupakan jendela yang digunakan untuk menambah kode program untuk pemrograman java.Tampilan

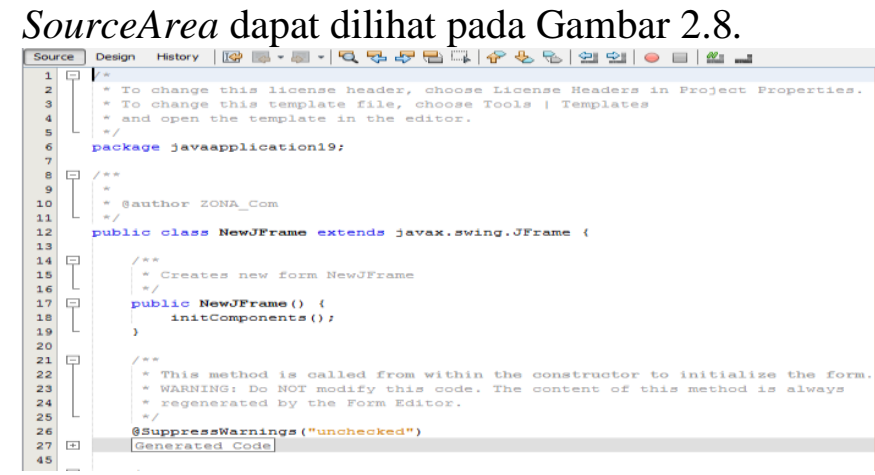

Gambar 2.8 Tampilan SourceArea

(Sumber: Printscrean)

\subsection{Komponen Palette Windows}

Komponen pada palette windows dibagi menjadi beberapa bagian yaitu:

Komponen pada swing container

Berikut Tools dan Fungsi komponen pada swing container pada tabel 2.1. Tabel 2.1 Fungsi komponen pada swing container:

\begin{tabular}{|l|l|}
\hline Tools & Fungsi \\
\hline$\square$ Panel & $\begin{array}{l}\text { Untuk } \\
\text { mengelompokkan } \\
\text { komponen-komponen. }\end{array}$ \\
\hline$][$ Split Pane & $\begin{array}{l}\text { Menampilkan dua } \\
\text { komponen dalam }\end{array}$ \\
\hline
\end{tabular}


Vol. 01, No. 02, Oktober 2020

\begin{tabular}{|c|c|}
\hline & $\begin{array}{lrr}\text { ruang yang tetap, } & \text { memungkinkan } & \text { user } \\
\text { mentuk menentukan } \\
\text { untuk } \\
\text { ukuran ruang yang } \\
\text { dipilih untuk setiap } \\
\text { komponen. }\end{array}$ \\
\hline $\bar{E}$ Tool Bar & $\begin{array}{l}\text { Sebagai tempat untuk } \\
\text { menampilkan tool-tool } \\
\text { yang bertujuan } \\
\text { mempermudah user } \\
\text { dalam mengoperasikan } \\
\text { beberapa tool-tool } \\
\text { yang mungkin sering } \\
\text { digunakan. }\end{array}$ \\
\hline$\square$ Internal Frame & $\begin{array}{lr}\begin{array}{l}\text { Merupakan } \\
\text { internal (di }\end{array} & \text { drame } \\
\text { frame } & \text { utama). } \\
\text { Membuat } & \text { banyak } \\
\text { window } & \text { (multi- } \\
\text { window) di dalam satu } \\
\text { frame. }\end{array}$ \\
\hline$\square$ Tabbed Pane & $\begin{array}{l}\text { Membuat frame yang } \\
\text { terdiri dari tab-tab } \\
\text { yang bisa dipilih oleh } \\
\text { user. }\end{array}$ \\
\hline \begin{tabular}{|l} 
目 Scroll Pane \\
\end{tabular} & 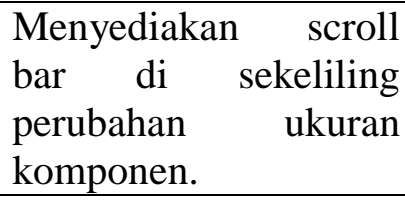 \\
\hline 듬 Desktop Pane & $\begin{array}{lr}\text { Digunakan } & \text { untuk } \\
\text { membuat } & \text { tampilan } \\
\text { MDI } & \text { (Multiple } \\
\text { Document Interface). }\end{array}$ \\
\hline$\$$ Layered Pane & $\begin{array}{l}\text { Menyediakan } \\
\text { lapis dimensi. }\end{array}$ \\
\hline
\end{tabular}

\subsection{Komponen pada swingcontrols}

Berikut Tools dan Fungsi komponen pada swingcontrols pada tabel 2.2. Tabel 2.2 Fungsi komponen pada swingcontrols:

\begin{tabular}{|l|l|}
\hline Tools & Fungsi \\
\hline wael Label & $\begin{array}{l}\text { Untuk memberikan } \\
\text { keterangan tambahan } \\
\text { atau identitas pada } \\
\text { tombol atau perintah }\end{array}$ \\
\hline
\end{tabular}

\begin{tabular}{|c|c|}
\hline & lainnya. \\
\hline ON Toggle Button & $\begin{array}{l}\text { Button yang selalu } \\
\text { berada dalam salah } \\
\text { satu dari dua kondisi. } \\
\text { Setiap klik pada } \\
\text { button akan merubah } \\
\text { dari kondisi satu ke } \\
\text { kondisi lainnya. }\end{array}$ \\
\hline - Radio Button & $\begin{array}{l}\text { Untuk meminta user } \\
\text { agar memilih salah } \\
\text { satu dari lebih dua } \\
\text { pilihan. Contoh } \\
\text { penggunaan adalah } \\
\text { ketika kita mengisi } \\
\text { data diri untuk pilihan } \\
\text { jenis kelamin. }\end{array}$ \\
\hline Combo Box & $\begin{array}{l}\text { Berfungsi untuk } \\
\text { menyisipkan beberapa } \\
\text { pilihan/ perintah, } \\
\text { sehingga dengan } \\
\text { combo box ini lebih } \\
\text { menghemat tempat, } \\
\text { karena dalam combo } \\
\text { box ini terdiri dari } \\
\text { beberapa pilihan. }\end{array}$ \\
\hline$\square$ Text Field & $\begin{array}{l}\text { Untuk membuat } \\
\text { kolom agar kelak bisa } \\
\text { diisi perintah-perintah } \\
\text { teks atau angka oleh } \\
\text { user. }\end{array}$ \\
\hline $\mathrm{OK}$ Button & $\begin{array}{ll}\text { Kontrol yang } & \text { tampil } \\
\text { pada layar } & \text { dengan } \\
\text { bentuk } & \text { persegi } \\
\text { panjang } & \text { dengan } \\
\text { tulisan yang } & \text { berada } \\
\text { ditengah. } & \\
\end{array}$ \\
\hline घ-Check Box & $\begin{array}{l}\text { Memilih lebih dari } \\
\text { satu pilihan, dengan } \\
\text { menyimpan data dan } \\
\text { akan menampilkannya } \\
\text { ketika di klik. }\end{array}$ \\
\hline ৪- Button Group & $\begin{array}{l}\text { Untuk } \\
\text { menggabungkan } \\
\text { seluruh button supaya } \\
\text { menjadi satu fungsi. }\end{array}$ \\
\hline
\end{tabular}


Jurnal Mahasiswa IImu Komputer (JMIK)

Vol. 01, No. 02, Oktober 2020

\begin{tabular}{|c|c|}
\hline 畻 List & $\begin{array}{l}\text { Untuk menampilkan } \\
\text { beberapa item. }\end{array}$ \\
\hline tx Text Area & $\begin{array}{l}\text { Untuk tempat } \\
\text { mengetik tulisan yang } \\
\text { berada di dalam kotak } \\
\text { yang mempunyai } \\
\text { fungsi scroll. }\end{array}$ \\
\hline 睤 Scroll Bar & $\begin{array}{l}\text { Untuk menggeser } \\
\text { jendela (windows) } \\
\text { secara vertikal. }\end{array}$ \\
\hline$\square$ Progress Bar & $\begin{array}{lr}\begin{array}{l}\text { Digunakan } \\
\text { menampilkan }\end{array} & \text { untuk } \\
\text { proses. } & \\
\end{array}$ \\
\hline ... Password Field & $\begin{array}{l}\text { Tempat untuk mengisi } \\
\text { password yang kita } \\
\text { miliki. }\end{array}$ \\
\hline$\forall$ Separator & $\begin{array}{l}\text { Berfungsi sebagai } \\
\text { sekat atau pemisah } \\
\text { antara garis yang ada } \\
\text { pada aplikasi atau } \\
\text { software yang } \\
\text { nantinya akan dibuat. }\end{array}$ \\
\hline Ed Editor Pane & $\begin{array}{l}\text { Sebuah panel yang } \\
\text { digunakan untuk } \\
\text { mengedit tulisan. }\end{array}$ \\
\hline 国 Table & $\begin{array}{l}\text { Untuk membuat tabel } \\
\text { pada aplikasi yang } \\
\text { nantinya akan kita } \\
\text { buat. }\end{array}$ \\
\hline Qb Slider & $\begin{array}{l}\text { Berfungsi sebagai } \\
\text { visualisasi proses } \\
\text { perjalanan dari sebuah } \\
\text { musik atau video. }\end{array}$ \\
\hline - -1 Formatted Field & $\begin{array}{l}\text { Untukn mengatur } \\
\text { format penulisan pada } \\
\text { field. }\end{array}$ \\
\hline 마 Spinner & $\begin{array}{lrr}\text { Berisi angka } & \text { yang } \\
\text { diletakkan } & \text { secara } \\
\text { ringkas atau berupa } \\
\text { daftar, ketika } & \text { kita } \\
\text { membutuhkan } & \text { angka } \\
\text { lebih kecil, } & \text { kita } \\
\text { tinggal klik } & \text { tanda } \\
\text { panah sampai muncul } \\
\text { angka yang } & \text { kita } \\
\text { inginkan } & \text { atau }\end{array}$ \\
\hline
\end{tabular}

\begin{tabular}{|l|l|}
\hline & sebaliknya. \\
\hline T Text Pane & $\begin{array}{l}\text { Menampilkan teks } \\
\text { format penulisan paa } \\
\text { field. }\end{array}$ \\
\hline 념 Tree & $\begin{array}{l}\text { Menampilkan data } \\
\text { dalam bentuk hirarkis. }\end{array}$ \\
\hline
\end{tabular}

Komponen pada Swing Menus:

Berikut Tools dan Fungsi komponen pada Swing menus pada tabel 2.3.

Tabel 2.3 Fungsi komponen pada Swing menus:

\begin{tabular}{|c|c|}
\hline Tools & Fungsi \\
\hline File Menu Bar & $\begin{array}{l}\text { Untuk } \\
\text { menciptakan tab- } \\
\text { tab menu yang } \\
\text { nantinya } \\
\text { dipergunakan } \\
\text { untuk perintah } \\
\text { menu yang } \\
\text { diinginkan. }\end{array}$ \\
\hline Menu & \begin{tabular}{l}
\multicolumn{2}{l}{ Membentuk } \\
perintah menu \\
yang masih bisa \\
dilanjutkan ke \\
menu \\
khusus. lebih
\end{tabular} \\
\hline- Menu Item & $\begin{array}{l}\text { Berisi perintah- } \\
\text { perintah spesifik } \\
\text { yang ada dalam } \\
\text { menu bar, bar, } \\
\text { sehingga } \\
\text { perintah-perintah } \\
\text { pada menu item } \\
\text { lebih khusus. }\end{array}$ \\
\hline - Menu Item / CheckBox & $\begin{array}{l}\text { Memberi tanda } \\
\text { (V) pada menu } \\
\text { perintah tertentu } \\
\text { supaya komputer } \\
\text { melakukan } \\
\text { seperti apa yang } \\
\text { kita perintahkan. }\end{array}$ \\
\hline O Menu Item / RadioButton & $\begin{array}{l}\text { Untuk } \\
\text { melakukan rating }\end{array}$ \\
\hline
\end{tabular}




\begin{tabular}{|c|c|}
\hline & $\begin{array}{l}\text { atau survey suatu } \\
\text { alamat website } \\
\text { atau digunakan } \\
\text { pada perintah } \\
\text { pemilihan } \\
\text { halaman cetakan } \\
\text { pada printer. }\end{array}$ \\
\hline Eopup Menu & \begin{tabular}{lr}
\multicolumn{2}{l}{ Menu yang akan } \\
tampil & secara \\
otomatis & atau \\
apabila & kita \\
menggerakkkan & \\
kursor & mouse \\
pada & area \\
tertentu. \\
Biasanya berisi \\
tentang informasi \\
$\begin{array}{l}\text { suatu } \\
\text { obyek/icon/menu }\end{array}$
\end{tabular} \\
\hline$\mapsto$ Separator & $\begin{array}{l}\text { Berfungsi } \\
\text { sebagai "sekat" } \\
\text { atau perintah } \\
\text { antara garis yang } \\
\text { ada pada aplikasi } \\
\text { atau software } \\
\text { yang nantinya } \\
\text { akan dibuat. }\end{array}$ \\
\hline
\end{tabular}

\subsection{Definisi Basis Data (Database)}

Basis Data ( database ) menurut Jogiyanto ( 2005:17) adalah kumpulan dari data yang saling berhubungan satu dengan yang lainnya tersimpan di perangkat keras komputer dan digunakan perangkat lunak untuk memanipulasinya. Database merupakan salah satu komponen yang penting dalam menyediakan informasi bagi para pemakai. Penerapan Database dalam sistem informasi disebut dengan database sistem, yaitu suatu sistem informasi yang mengintegrasikan kumpulan dari data yang saling berhubungan satu dengan yang lainnya dan membuatnya tersedia untuk beberapa aplikasi yang bermacam-macam di dalam suatu organisasi.
Dari definisi basis data diatas maka penulisan menyimpulkan bahwa basis data dapat dianggap tempat untuk sekumpulan berkas data terkomputerisasi, dengan tujuan utama memelihara informasi dan membuat informasi tersebut tersedia saat dibutuhkan.

\subsection{Appserv}

Firdaus (2007:2), “Appserv merupakan sebuah paket data apache, PHP, MySQL, dalam PhpMyAdmin sehingga tidak perlu melakukan konfigurasi yang sulit". Software yang digunakan untuk database secara grafis/gambar, software ini memudahkan para desain web dalam membuat database daripada cmd.exe yang penulisannya manual dan basis.text. Berdasarkan pendapat diatas dapat ditarik kesimpulan Appserv adalah software basisdata, Mysql, pHp, phpMyadmin dilengkapi dengan server Apache.

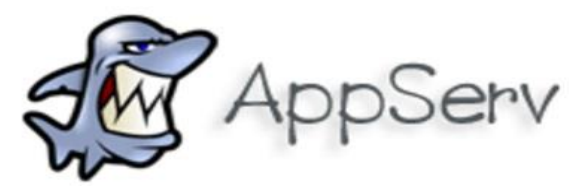

Gambar 2.9 Logo Appserv

(Sumber: Google)

\subsection{8 iReport}

Riestiana (2014:34) menarik kesimpulan sebagai berikut:

iReport merupakan perangkat lunak bantu untuk perancangan laporan secara visual yang nantinya dapat di kompilasi dengan menggunakan jasperReport sehingga menjadi file *jasper atau *jrxml yang dapat langsung dipanggil oleh pemrograman java. Berikut Tampilan ireport dapat dilihat pada Gambar 2.10. 


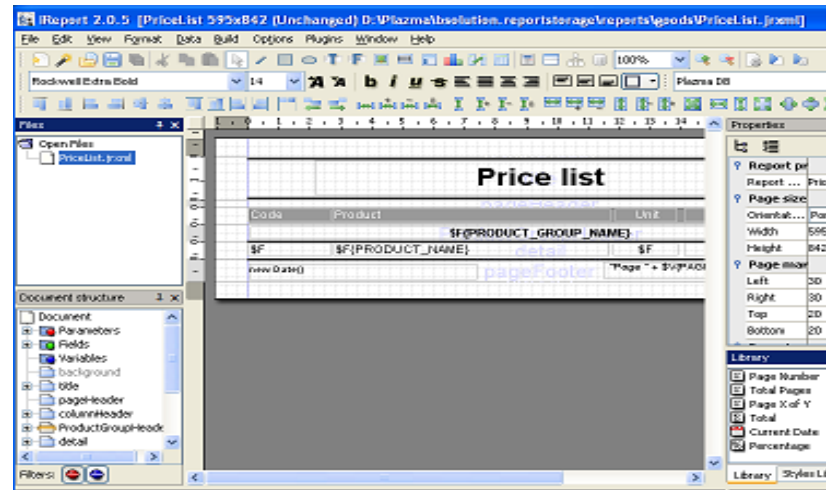

Gambar 2.10 Tampilan Ireport

(Sumber: Printscrean)

\section{METODE}

Metodologi adalah kesatuan metode-metode, prosedur, konsep-konsep, pekerjaan atau aturan yang digunakan oleh suatu ilmu pengetahuan. Memperoleh data guna menyusun Tugas Akhir, penulis menggunakan metode-metode yaitu sebagai berikut:

\section{Studi Lapangan}

Studi lapangan adalah pengumpulan data dan informasi dari tempat penelitian, atas masalah yang sedang dihadapi. Adapun studi lapangan yang penulis lakukan adalah dengan teknik:

$\sqrt{ }$ Wawancara (Interview)

Interview adalah metode pengumpulan data dengan cara wawancara atau tanya jawab secara langsung dengan petugas apoteker yang bersangkutan dengan ini penulis melakukan wawancara secara langsung dengan Luthfiyana Ulfah, S.Farm selaku asisten apoteker di Klinik Hadi Wijaya Kota Metro. Terlampir tabel wawancara.

\section{$\checkmark$ Pengamatan (Observasi)}

Observasi adalah metode pengumpulan data dengan cara pengamatan langsung kegiatan operasional yuang berlangsung di Klinik Hadi Wijaya Kota Metro. Terlampir dokumentasi foto.

\section{$\checkmark$ Dokumentasi (Documentation)}

Dokumentasi adalah metode pengumpulan data dengan cara mengambil gambar dan mengumpulkan dokumen atau arsip yang dibutuhkan untuk peneltian. Terlampir dokumen-dokumen.

\section{Studi Pustaka}

Metode yang dilakukan dengan mengambil bahan bacaan dari buku-buku yang berada pada perpustakaan kampus maupun di luar kampus yang berkaitan dengan tugas akhir.

\section{PEMBAHASAN}

\subsection{Hasil Penelitian}

Dalam melakukan penelitian pada Klinik Hadi Wijaya Kota Metro, penulis menemukan adanya kekurangan dalam proses pengolahan data obat. Pengolahan data obat di Klinik Hadi Wijaya Kota Metro masih menggunakan buku besar. Sulitnya pencarian data stok obat karena banyaknya jumlah nama obat dalam data yang disimpan dalam buku besar. Proses pembuatan Laporan bulanan obat yang akan dilaporkan ke Kepala Klinik tidak efektif dan efisien.

\subsection{Perancangan Aplikasi}

Dalam merancang suatu program diperlukan beberapa tahap untuk menentukan arah dari program tersebut. Sama seperti yang penulis lakukan dalam membuat aplikasi ini. Dimulai dari pengumpulan data, analisa sistem, menentukan dan membuat alur sistem, membuat relasi tabel, membuat database, merancang tampilan program, sampai pada hasil pembuatan program (Output). Berdasarkan analisa sistem diperoleh pengolahan data obat pada Klinik Hadi Wijaya Kota Metro.

\subsection{Tujuan dan Kegunaan Perancangan Sistem}

Tujuan perancangan sistem ini adalah untuk menganalisis aplikasi pengolahan data obat pada Klinik Hadi Wijaya Kota Metro. Perancangan ini diusulkan sebagai bahan masukan yang dapat dipertimbangkan untuk 
mengetahui stok obat dan mempercepat proses pembuatan laporan khususnya untuk pengelolahan data obat pada Klinik Hadui Wijaya Kota Metro.

\subsection{Gambaran Umum Sistem Yang Diusulkan}

Sistem Informasi yang diusulkan memiliki beberapa keunggulan dari sistem yang sedang berjalan. Sistem yang ini lebih mudah digunakan oleh asisten apoteker, dan mempercepat pencarian data stok obat yang ada serta pembuatan laporan pemakaian obat perbulan.

\subsection{Perancangan Prosedur Yang Diusulkan}

Pada tahapan perancangan prosedur ini bertujuan untuk menghasilkan perancangan aplikasi pengolahan data obat yang berbasis komputer. Adapun perancangan proses ini mencakup aliran sistem informasi, diagram context, data flow diagram yang dapat menjelaskan aliran data yang diproses hingga menghasilkan informasi yang diinginkan.

Kebutuhan Sumber Daya

Perangkat Keras (Hardware)

Rancangan hardware yang diusulkan penulis untuk dipergunakan dalam iimplementasi sistem yang dirancang adalah:
a. Procecor Intel Inside
b. Memory (RAM) 2GB
c. 1 Unit printer
d. Hardisk 500GB
e. Keyboard
f. Mouse
g. Monitor

\section{Perangkat Lunak (Software)}

Pada rancangan ini penulis menggunakan beberapa perangkat lunak yang mendukung dalam perancangan data obat. Adapun spesifikasi perangkat lunak yang digunakan yaitu :

a. Sistem Operasi Microsoft Windows 7 b. NetBeans IDE 8.0.2

c. $M y S Q L$

Perangkat Pikir (Brainware)

Untuk melaksanakan aplikasi yang sudah dirancang yaitu mengolah data obat pada UPTD Klinik Hadi Wijaya Kota Metro dibutuhkan 1 orang karyawan yaitu pada bagian apotik. Untuk pengolahan data obat dan pembuatan laporan.

\subsection{Aliran Sistem Informasi}

Rancangan Aliran Informasi Pengolahan data obat pada Klinik Hadi Wijaya Kota Metro dan pembuatan Laporan obat yang akan dirancang adalah sebagai berikut:

Menurut Analisis yang penulis lakukan di Klinik Hadi Wijaya Kota Metro tentang Pengolahan Data Obat, dapat diuraikan sebagai berikut.

Aliran informasi pengolahan data obat pada Klinik Hadi Wijaya Kota Metro dimulai dari asisten apoteker menginputkan data obat masuk dan obat keluar yang akan disimpan dalam database dengan masing-masing tabel yaitu: tb_obat, tb_data_obat_masuk, tb_data_obat_keluar. Dari tabel-tabel tersebut asisten apoteker membuat laporan stok obat, data obat masuk, data obat keluar yang akan diberikan kepada Kepala Klinik Hadi Wijaya Kota Metro.

4.7 Rancangan Data Flow Diagram (DFD) Data Flow Diagram (DFD) atau Diagram Aliran Data merupakan model dari sistem untuk meggambarkan pembagian sistem ke modul yang lebih kecil. Salah satu keuntungan menggunakan diagram alur data adalah memudahkan pemakai atau user yang kurang menguasai bidang komputer untuk mengerti sistem yang akan dikerjakan.

Berikut merupakan gambar Data Flow Diagram Level pada Gambar 4.1: 


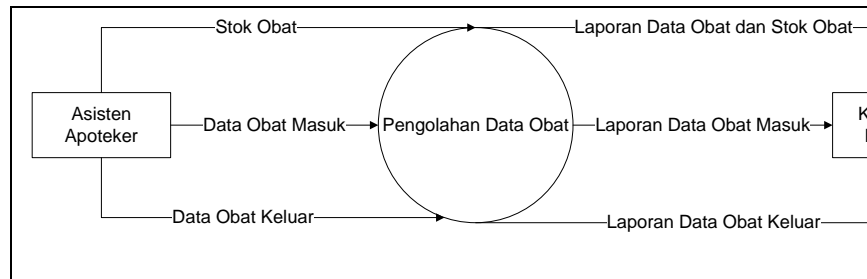

Gambar 4.1 Data Flow Diagram Level 0

Data Flow Diagram Level 1 merupakan turunan dari Data Flow Diagram Level 0. Berikut gambar Data Flow Diagram Level 1 pada gambar 4.2
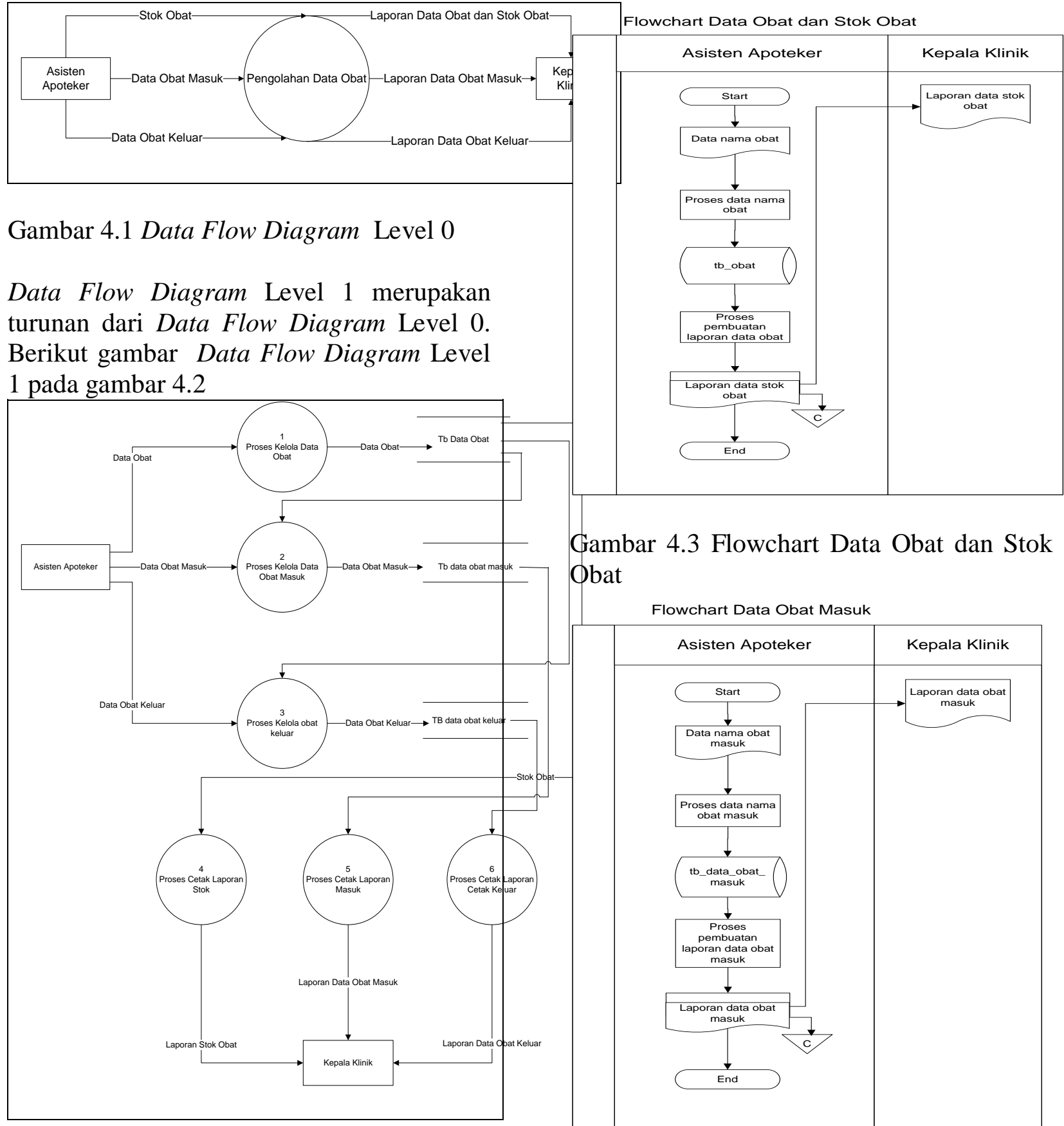

Gambar 4.3 Flowchart Data Obat dan Stok Obat

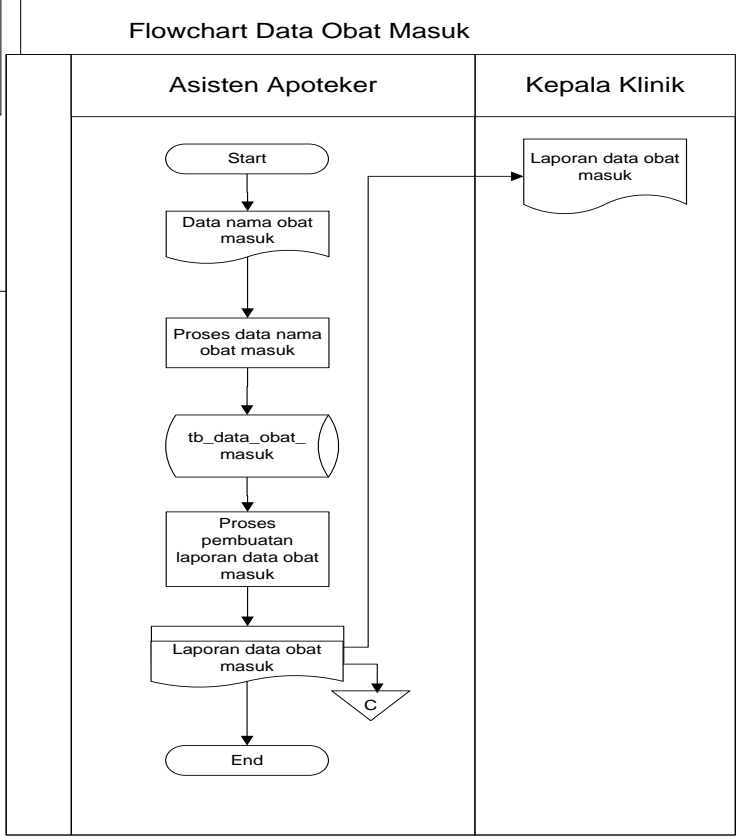

Gambar 4.2 Data Flow Diagram Level 1

Gambar 4.4 Flowchart Data Obat Masuk

\subsection{Rancangan Flowchart}

Bagan alir (Flowchart) adalah bagan (Chart) yang menunjukkan alir (Flow) di dalam program atau prosedur sistem secara logika. Rancangan flowchart dapat dilihat pada gambar di bawah ini: 
Jurnal Mahasiswa IImu Komputer (JMIK)

Vol. 01, No. 02, Oktober 2020

Flowchart Data Obat Keluar

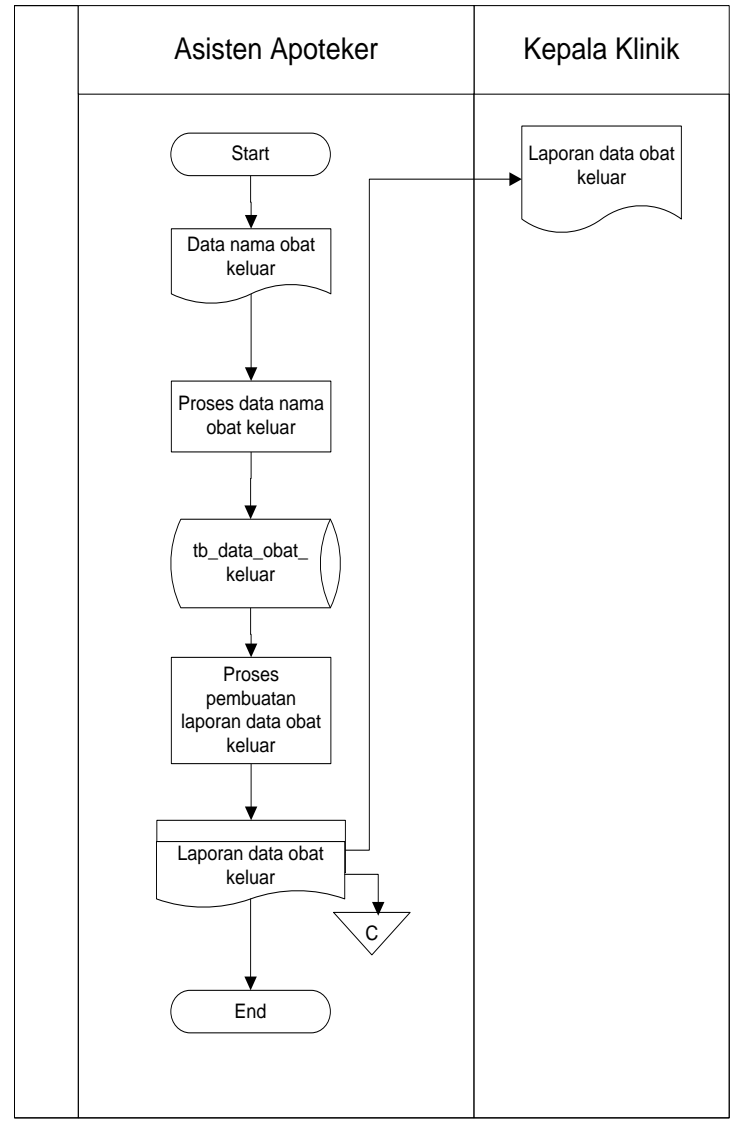

Gambar 4.5 Flowchart Data Obat Keluar

4.9 Rancangan Entity Relationship Diagram (ERD)

Entity Relationship Diagram adalah alat pemodelan data utama dan akan membantu mengorganisasi data dalam satu proyek kedalam entitas-entitas dan menentukan hubungan aterintitas. Proses memungkinkan analis menghasilkan struktur basisdata yang baik sehingga dapat disimpandan diambil secara efisien.

Berikut ini Gambar 4.6 adalah rancangan ERD file database dan hubungan antar entity:

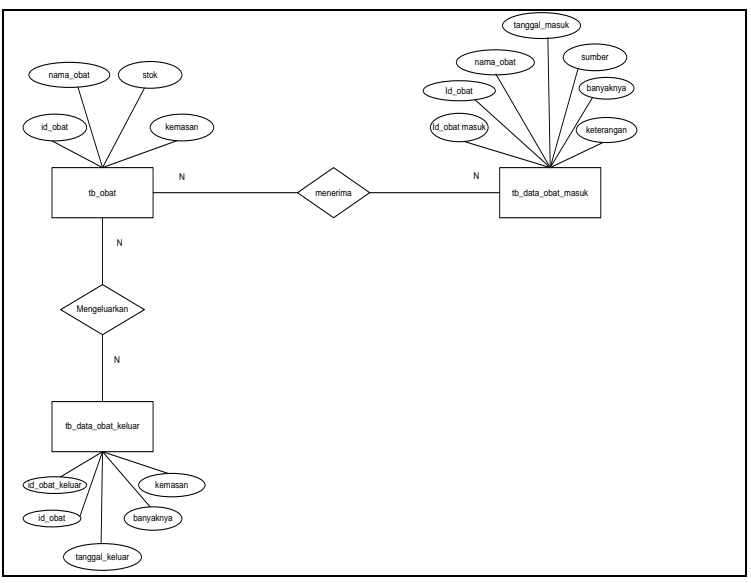

Gambar 4.6 Rancangan ERD file database dan hubungan antar entity

\subsection{Relasi Tabel}

Adapun rancangan database dapat dilihat pada relasi tabel pada Gambar 4.7.

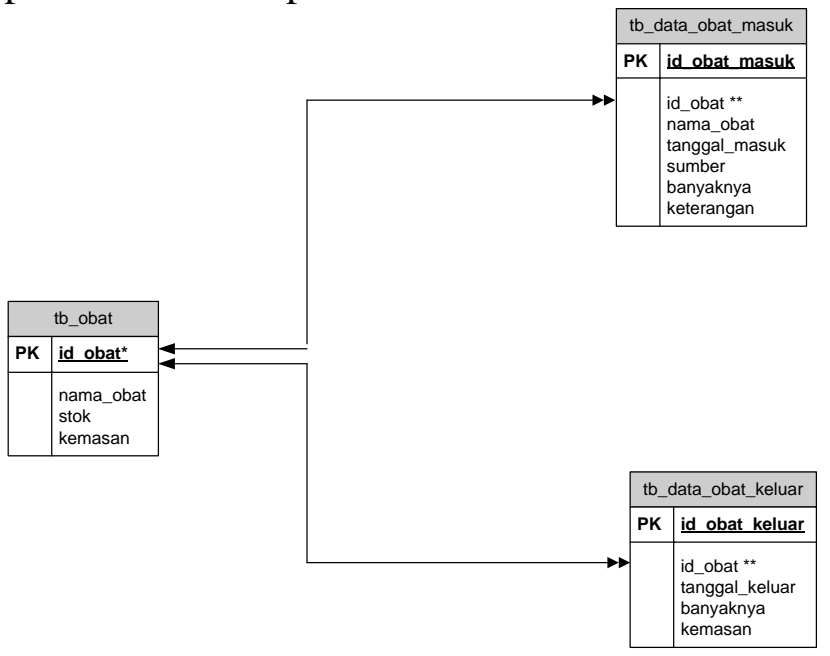

Gambar 4.7 Relasi Tabel

Keterangan:

$(*) \quad$ : Primary Key

$(* *)$ : Foreign Key

\subsection{Rancangan File/Basis Data}

Basis data adalah mekanisme yang digunakan untuk menyimpan informasi atau 
data. Dengan basis data, pengguna dapat menyimpan data secara terorganisasi. Setelah data disimpan, informasi harus mudah diambil. Cara data disimpan dalam basis data menentukan seberapa mudah mencari informasi berdasarkan banyak kriteria, data pun harus mudah ditambahkan ke dalam basis data, dimodifikasi, dan dihapus.

Tabel Data Obat Masuk

Adapun tabel data obat masuk yang digunakan untuk menyimpan data obat masuk yang telah diinputkan. Seperti pada tabel 4.1 di bawah ini.

Nama tabel : tb_data_obat_masuk Attribute : id_obat_masuk, id_obat,.

Primary Key : id_obat_masuk

Foreigen Key : id_obat

Tabel 4.1 Rancangan basis data tabel data obat masuk

\begin{tabular}{|l|l|l|l|}
\hline Nama Field & Type & Lenght & Keterangan \\
\hline *id_obat_masuk & Varchar & 11 & Id obat masuk \\
\hline$* *$ id_obat & Varchar & 10 & Id obat \\
\hline nama_obat & Varchar & 50 & Nama Obat \\
\hline tanggal_masuk & Date & - & Tanggal \\
\hline sumber & Varchar & 50 & Sumber \\
\hline banyaknya & Int & 10 & Banyaknya \\
\hline keterangan & Varchar & 50 & Keterangan \\
\hline
\end{tabular}

\subsection{Tabel obat}

Adapun tabel data stok obat yang digunakan untuk menyimpan data stok yang telah diinputkan. Seperti pada tabel 4.2 di bawah ini.

Nama tabel : tb_obat

Attribute : id_obat, nama_obat, stok,kemasan.

Primary Key : id_obat

Tabel 4.2 Rancangan basis data Tabel data obat obat

\begin{tabular}{|l|l|l|l|}
\hline Nama_Field & Type & Lenght & Keterangan \\
\hline *id_obat & Varchar & 10 & Id_stok \\
\hline
\end{tabular}

\begin{tabular}{|l|l|l|l|}
\hline nama_obat & Varchar & 50 & Nama_obat \\
\hline Stok & Varchar & 10 & Stok \\
\hline Kemasan & Varchar & 50 & Kemasan \\
\hline
\end{tabular}

\subsection{Tabel data obat keluar}

Adapun tabel data obat keluar yang akan digunakan untuk menyimpan data obat keluar yang telah diinputkan. Seperti pada tabel 4.3 di bawah ini.

Nama tabel tabel_data_obat_keluar

Attribute :id_obat_keluar, id_obat, tgl_keluar, banyaknya, kemasan.

Primary Key : id_obat_keluar

Foreigen Key : id_obat

Tabel 4.3 Rancangan basis data tabel data obat keluar

\begin{tabular}{|l|l|l|l|}
\hline Nama Field & Type & Lenght & Keterangan \\
\hline $\begin{array}{l}* \\
\text { id_obat_keluar }\end{array}$ & Varchar & 10 & Id obat keluar \\
\hline$* *$ id_obat & Varchar & 10 & Id obat \\
\hline tanggal_keluar & Date & - & Tanggal \\
\hline Banyaknya & Int & 10 & Banyaknya \\
\hline Kemasan & Varchar & 50 & Kemasan \\
\hline
\end{tabular}

\subsection{Rancangan Antar Muka Sistem \\ Rancangan Login}

Tampilan ini berfungsi sebagai tempat untuk memasukkan username dan password saat akan melakukan input data obat masuk. Adapun rancangan login dapat dilihat pada Gambar 4.8.

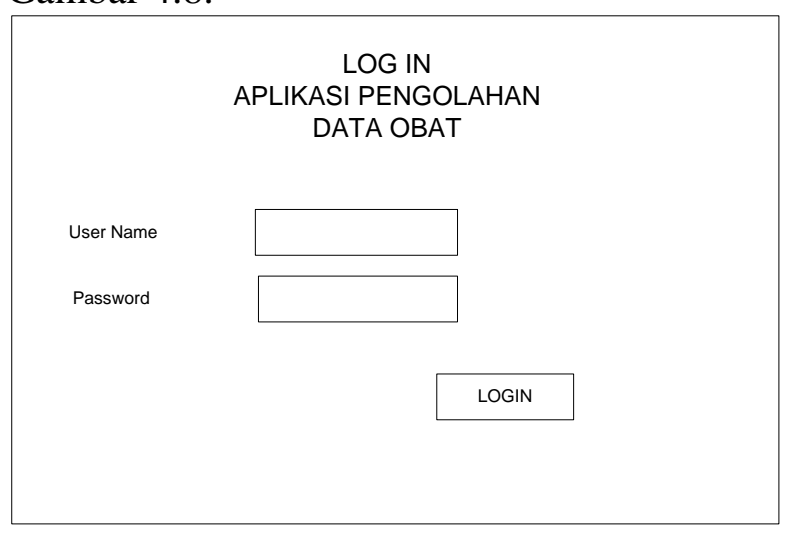

Gambar 4.8 Rancangan Tampilan Login

\subsection{Rancangan Input}

Rancangan input data obat masuk 
Tampilan ini berfungsi sebagai tempat untuk memasukkan data obat masuk sehingga ketika saat pengguna akan melakukan input data obat masuk maka akan mempermudah dalam pencarian. Adapun rancangan input data obat masuk dapat dilihat pada Gambar 4.9 .

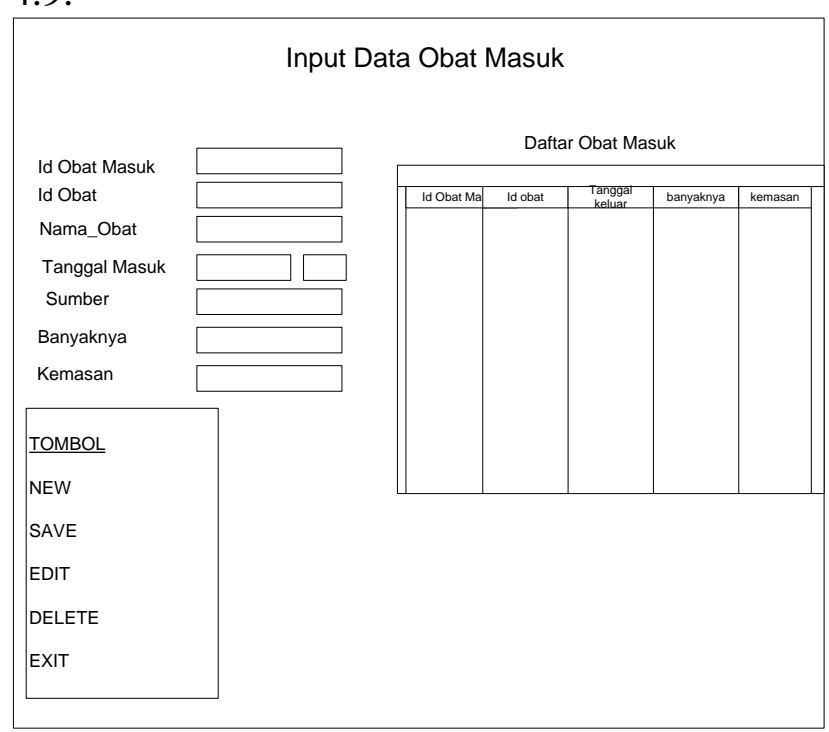

Gambar 4.9 Rancangan tampilan form data obat masuk

Penjelasan fungsi-fungsi tombol:

Tambah : Menambah data

Simpan : Menyimpan data.

Edit : Merubah data-data yang dianggap salah.

Hapus : menghapus data.

\subsection{Rancangan input tabel data obat keluar}

Tampilan ini berfungsi sebagai tempat untuk memasukkan data obat keluar sehingga ketika saat pengguna akan melakukan input data obat keluar maka akan mempermudah dalam pencarian. Adapun rancangan input data obat keluar dapat dilihat pada Gambar 4.10 .

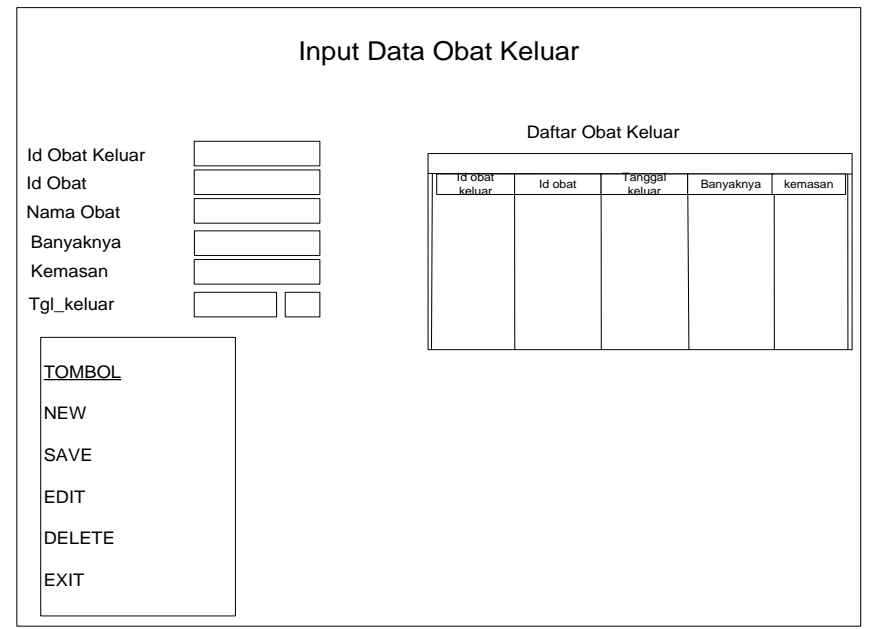

Gambar 4.10 Rancangan tampilan form data obat keluar

Penjelasan fungsi-fungsi tombol:

Tambah : Menambah data

Simpan : Menyimpan data.

Edit : Merubah data-data yang dianggap salah.

Hapus : menghapus data.

\subsection{Rancangan input tabel data obat}

Tampilan ini berfungsi sebagai tempat untuk mengetahui banyaknya data obat serta stok obat sehingga ketika saat pengguna akan melakukan pengecekan obat maka akan lebih cepat. Adapun rancangan input data obat dapat dilihat pada Gambar 4.11

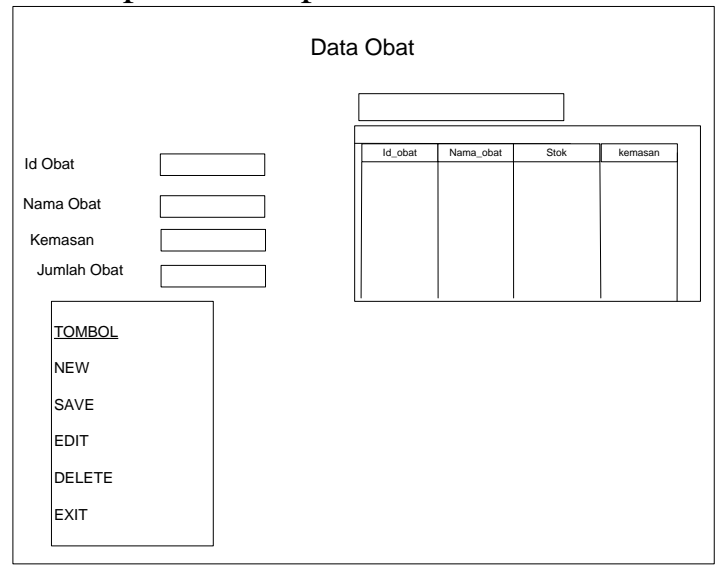

Gambar 4.11 Rancangan tampilan form data obat 
Penjelasan fungsi-fungsi tombol:

Tambah : Menambah data

Simpan : Menyimpan data.

Edit : Merubah data-data yang dianggap salah.

Hapus : menghapus data.

\subsection{Rancangan tampilan cetak laporan}

Tampilan ini berfungsi untuk mencetak laporan data obat masuk, data obat keluar, dan data stok obat perbulan, adapun tampilannya dapat dilihat pada gambar 4.12.

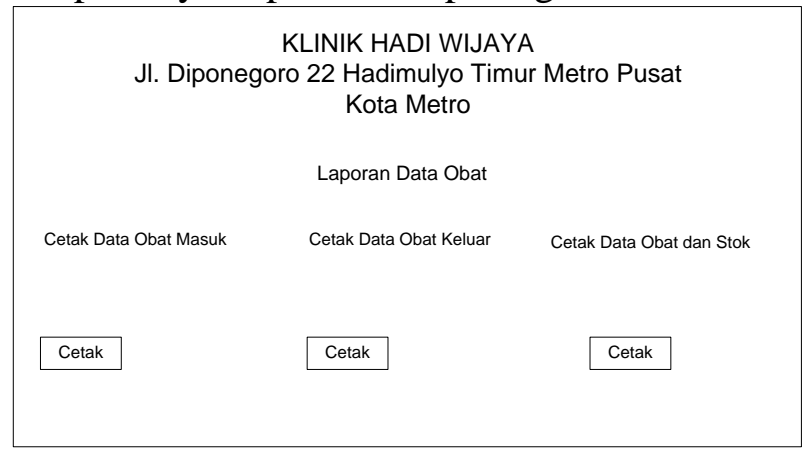

Gambar 4.12 Rancangan tampilan cetak laporan

\subsection{Rancangan Output}

Laporan data obat masuk

Tampilan ini berfungsi untuk mengetahui banyaknya obat masuk di Klinik Hadi Wijaya Kota Metro. Adapun rancangan output Laporan obat masuk yang telah diinputkan dapat dilihat pada gambar 4.13.

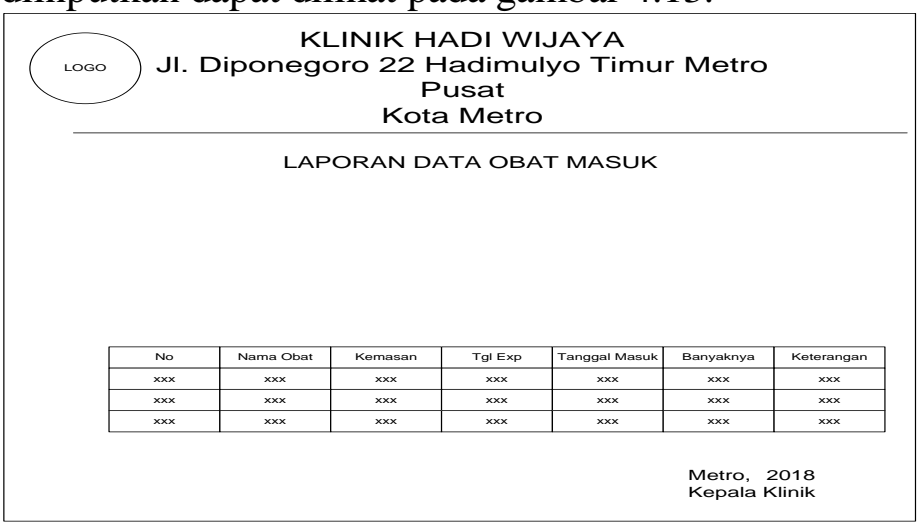

Gambar 4.13 Rancangan output laporan data obat masuk

\subsection{Laporan data obat}

Tampilan ini berfungsi untuk mengetahui banyaknya obat yang ada di Klinik Hadi Wijaya Kota Metro. Adapun rancangan output Laporan obat yang telah diinputkan dapat dilihat pada gambar 4.14.

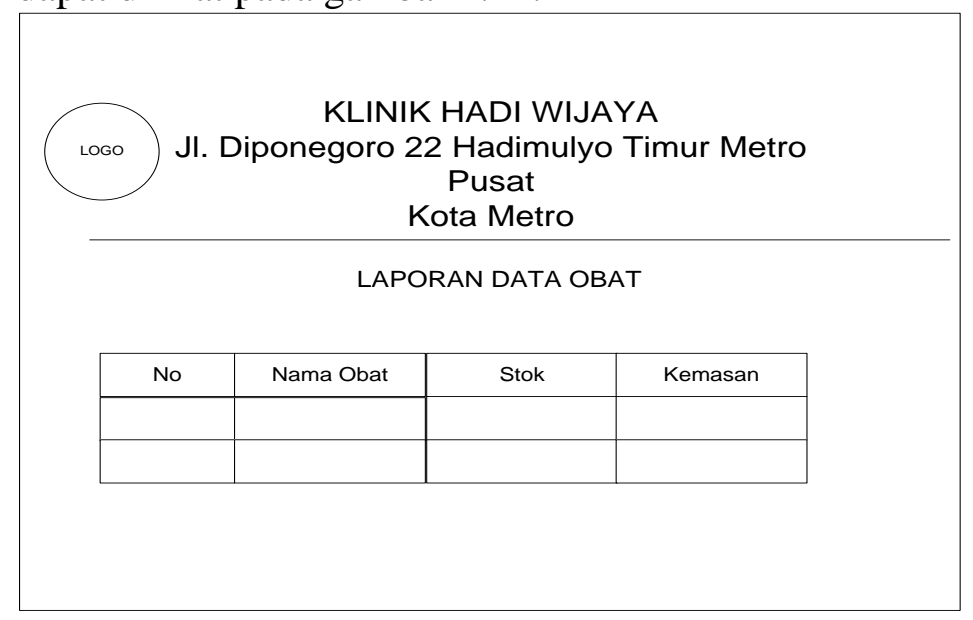

Gambar 4.14 Rancangan output laporan data obat

\subsection{Laporan data obat keluar}

Tampilan ini berfungsi untuk mengetahui banyaknya obat keluar di Klinik Hadi Wijaya Kota Metro. Adapun rancangan output Laporan obat keluar yang telah diinputkan dapat dilihat pada gambar 4.15. 


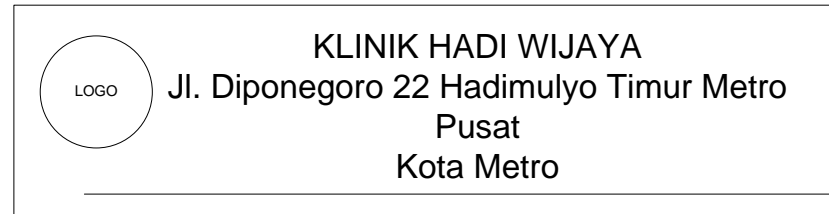

LAPORAN DATA OBAT KELUAR

\subsection{Menu Utama}

Tampilan menu utama terdiri dari Menu Data, Menu Report, dan Menu Keluar, yang berfungsi untuk pengguna aplikasi pengolahan data obat Klinik Hadi Wijaya Kota Metro. Terdiri dari menu Data di dalamnya ada data obat masuk, data obat, dan data obat keluar. Menu Report di dalamnya ada laporan data obat masuk, laporan data obat, dan laporan data obat keluar. Menu Keluar hanya untuk keluar dari

\begin{tabular}{|c|c|c|c|c|c|c|}
\hline No & Nama Obat & Kemasan & Banyaknya & Tanggal & $\begin{array}{c}\text { Yang } \\
\text { Menerima }\end{array}$ & Keteranga \\
\hline $\mathrm{xxx}$ & $\mathrm{xxx}$ & $\mathrm{xxx}$ & $\mathrm{xxx}$ & $\mathrm{xxx}$ & $\mathrm{xxx}$ & $\mathrm{xxx}$ \\
\hline $\mathrm{xxx}$ & $\mathrm{xxx}$ & $\mathrm{xxx}$ & $\mathrm{xxx}$ & $\mathrm{xxx}$ & $\mathrm{xxx}$ & $\mathrm{xxx}$ \\
\hline $\mathrm{xxx}$ & $\mathrm{xxx}$ & $\mathrm{xxx}$ & $\mathrm{xxx}$ & $\mathrm{xxx}$ & $\mathrm{xxx}$ & $\mathrm{xxx}$ \\
\hline
\end{tabular}

Metro, 2018 Kepala Klinik

Gambar 4.15 Rancangan output laporan data obat keluar

\subsection{Pembahasan Program}

Pembahasan aplikasi bertujuan untuk memberikan interface tentang desain program yang dibuat.

Tampilan Login

Tampilan Form Login ini berfungsi sebagai tempat untuk memasukkan username dan password saat akan melakukan input Data Obat, dapat dilihat pada gambar 4.16.

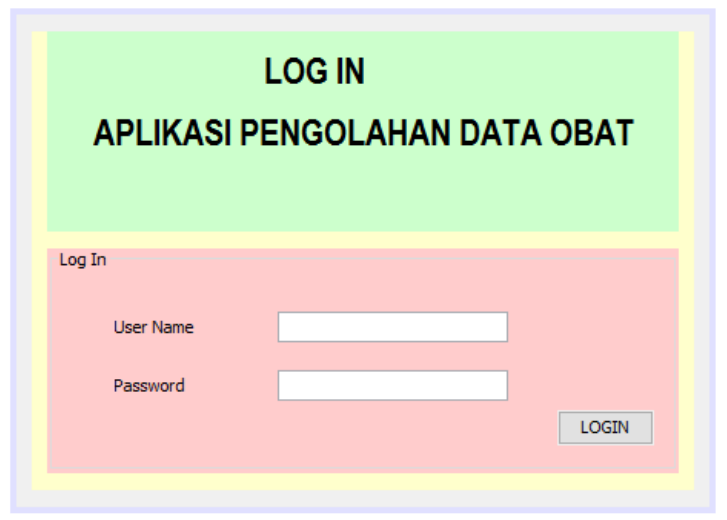

Gambar 4.16 Tampilan Login
Gambar 4.17 Tampilan Menu Utama

\subsection{Form Input}

Form Data Obat Masuk

Tampilan data obat masuk berfungsi memasukkan data obat yang diterima Klinik dapat dilihat pada gambar 4.18.

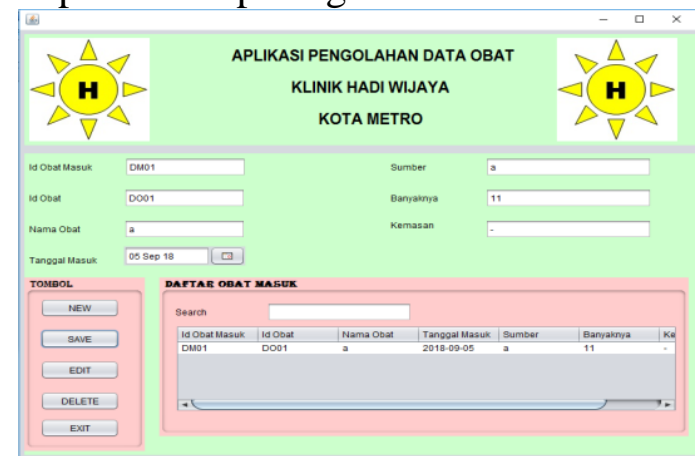

Gambar 4.18 Tampilan data obat masuk

\subsection{Form Data Obat}

Tampilan data obat berfungsi melihat jumlah obat yang masih tersedia di Klinik dapat dilihat pada gambar 4.19. 
Jurnal Mahasiswa IImu Komputer (JMIK)

Vol. 01, No. 02, Oktober 2020

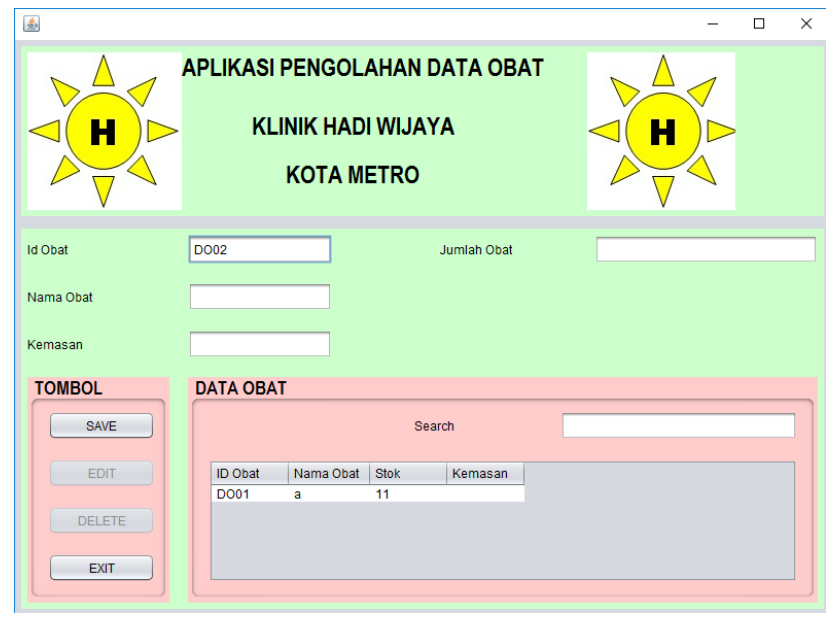

Gambar 4.19 Tampilan data obat dan stok

\subsection{Form data obat keluar}

Tampilan data obat keluar berfungsi mengetahui jumlah obat yang dikeluarkan dari Klinik dapat dilihat pada gambar 4.20.

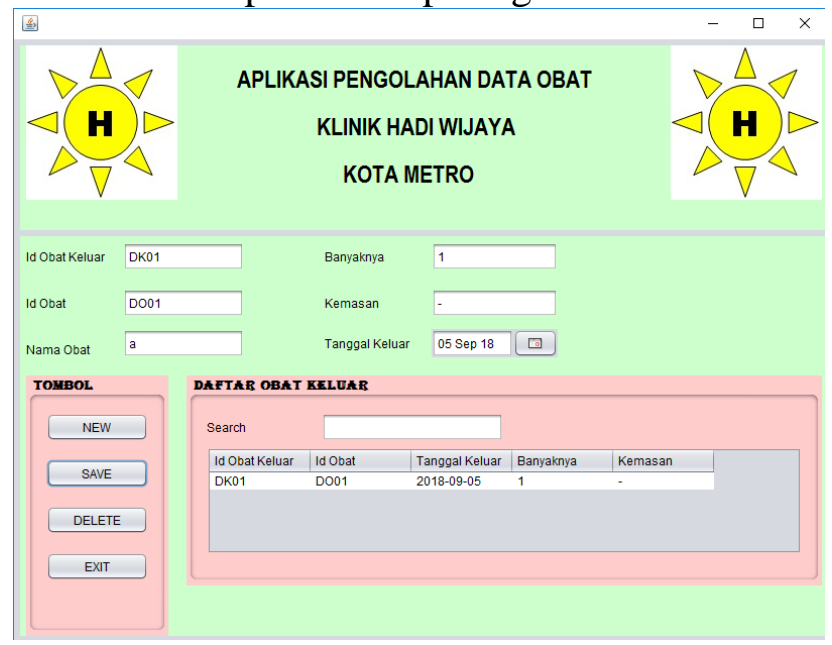

Gambar 4.20 Tampilan data obat keluar

\subsection{Form Output}

Form laporan data obat masuk

Tampilan laporan data obat masuk berfungsi sebagai hasil akhir inputan yang dilakukan oleh admin untuk dijadikan sebagai laporan data obat masuk pada Klinik Hadi Wijaya Kota Metro. Adapun form output data obat masuk dapat dilihat pada gambar 4.21.

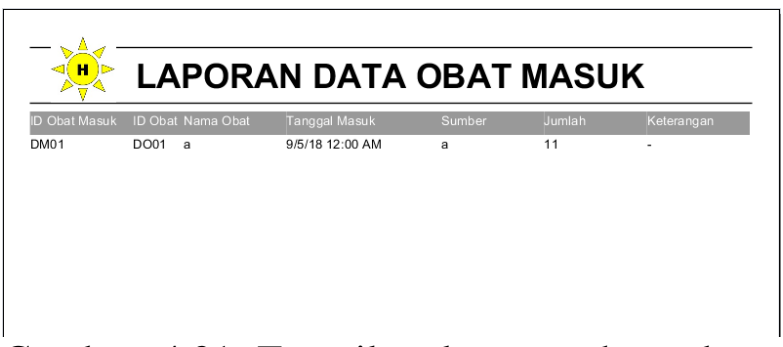

Gambar 4.21 Tampilan laporan data obat masuk

\subsection{Form laporan data obat}

Tampilan laporan data obat berfungsi untuk mengetahui jumlah stok obat yang masih tersedia dan akan dijadikan laporan data stok obat oleh admin di Klinik Hadi Wijaya Kota Metro. Adapun form output data stok obat dapat dilihat pada gambar 4.22.

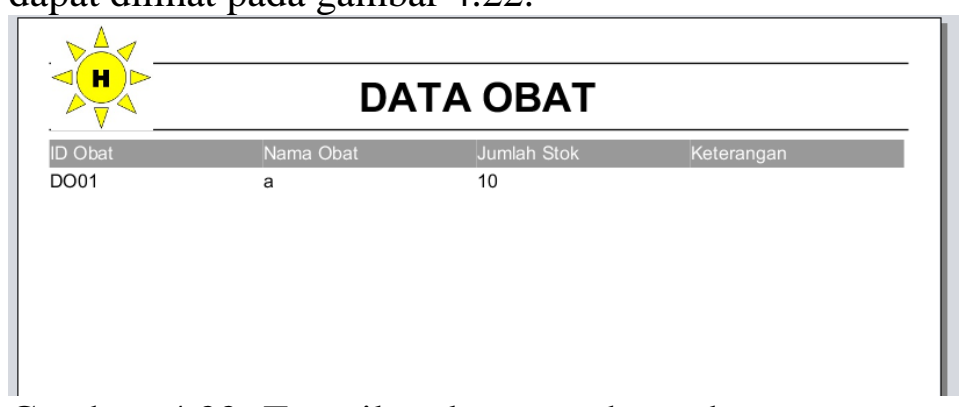

Gambar 4.22 Tampilan laporan data obat dan stok

\subsection{Form laporan data obat keluar}

Tampilan laporan data obat keluar berfungsi mengetahui banyaknya obat yang keluar dilakukan oleh admin untuk dijadikan sebagai laporan data obat keluar pada Klinik Hadi Wijaya Kota Metro. Adapun form output data obat keluar dapat dilihat pada gambar 4.23.

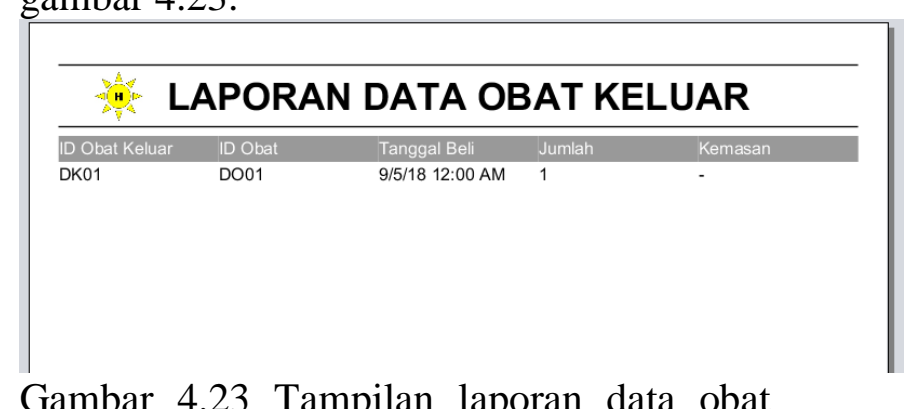

Gambar 4.23 Tampilan laporan data obat keluar 
4.30 Kelebihan dan Kekurangan Program Adapun kelebihan dan kekurangan program yang telah dirancang adalah sebagai berikut: Kelebihan program

$\sqrt{ }$ Program yang dirancang penulis memiliki beberapa kelebihan yaitu:

$\sqrt{ }$ Program yang di rancang sudah menggunakan Login User, untuk membantu keamanan pengoprasian aplikasi.

$\sqrt{ }$ Membantu dalam pengolahan data dalam pembuatan laporan lebih efesien.

$\sqrt{ }$ Mempermudah admin dalam mengolah data obat.

$\sqrt{ }$ Mempermudah admin dalam proses input, edit, hapus, cari maupun penyimpanan data obat.

$\sqrt{ }$ Pencarian data obat dan stok lebih mudah dicari.

Kekurangan Program

Program yang dirancang oleh penulis jauh dari kata sempurna, kekurangan dari program ini adalah sebagai berikut:

$\sqrt{ }$ Program yang digunakan belum sepenuhnya bisa mengatasi masalahmasalah yang ada dalam pengolahan data obat.

$\checkmark$ Data obat masuk, data obat keluar, dan data obat tidak dapat diakses secara online.

$\sqrt{ }$ Aksesnya masih menggunakan database MySQL dan belum berbasis server.

\section{KESIMPULAN}

Setelah memahami dan menganalisis masalah yang terjadi, maka penulis dapat mengambil kesimpulan bahwa proses pengolahan Data obat selama ini berjalan cukup baik, namun proses pengolahan data tersebut masih dilakukan secara manual, yaitu dengan menggunakan buku besar sehingga menimbulkan permasalahan yang sulit, pembuatan laporan yang kurang efektif.

Dengan menggunakan aplikasi yang baru, pengolahan data obat dapat meningkatkan kinerja petugas diantaranya adalah sebagai berikut:

$\sqrt{ }$ Memperbaiki pengolahan data obat pada klinik hadi wijaya kota Metro.

$\checkmark$ Mempercepat laporan data obat yang akan dilaporkan kepada kepala klinik dan mengetahui stok obat yang ada.

\section{Saran}

Berdasarkan kesimpulan diatas, saran untuk proram ini adalah sebagai berikut:

$\sqrt{ }$ Dalam pembuatan aplikasi ini, penulis berharap agar sistem yang diteliti dapat lebih baik kepadanya dan penulis membuat aplikasi sesuai dengan pengamatan yang dilakukan pada klinik hadi wijaya kota Metro.

$\sqrt{ }$ Jika dalam pembuatan aplikasi atau desain terdapat suatu kekurangan, khususnya dalam hal antar muka penulis berharap untuk pengembangan lebih lanjut dapat ditingkatkan.

$\sqrt{ }$ Lebih ditingkatkan pengetahuan tentang aplikasi pengolahan data obat yang telah dirancang guna menciptakan aplikasi yang jauh lebih baik dan sesuai yang diharapkan oleh klinik hadi wijaya kota Metro.

\section{DAFTAR PUSTAKA}

[1] Sofyan, Asep Abdul dkk. 2015. Perancangan Aplikasi Sistem Pakar Deteksi Dini Kerusakan Mobil Toyota Avanza. JURNAL SISPOTEK GLOBAL (Online.). Vol.5. No.4. 
Jurnal Mahasiswa IImu Komputer (JMIK)

Vol. 01, No. 02, Oktober 2020

[2] Afrizal, Ali Subhan. 2014. RANCANG BANGUN APLIKASI DESKTOP KAMUS INDONESIA, INGGRIS DAN ARAB MENGGUNAKAN NETBEANS DAN MYSQL. Jurnal Teknik Informatika Politeknik Sekayu (TIPS). Vol.20. No.1.

[3] Kusumawardani, Lia dan Wardati Indah Uly. 2014. Analisis Dan Perancangan Sistem Informasi Hotel Graha Prima Pacitan. Journal Speed Sentra Penelitian Engineering dan Edukasi. Vol.6. No.3.

[4] Arman. Sistem Informasi Pengolahan Data Penduduk Nagari Tanjung Lolo, Kecamatan Tanjung Gadang, Kabupaten Sijunjung Berbasis Web. Jurnal Edik Informatika Penelitian Bidang Komputer Sains dan Pendidikan Informatika.

[5] Irawati, Erni dkk. Sistem Informasi Pengolahan Data Pasien Rawat Inap Pada Klinik PKU Muhammadiyah Pacitan. Indonesian Jurnal on Computer Science.

Nugroho, Adi. 2004. PERANCANGAN dan IMPLEMENTASI SISTEM BASISDATA. Yogyakarta: Andi.

[6] Utomo, Eko Priyo. 2013. Cara Cepat dan Mudah Belajar Java SE7. Yogyakarta: Andi.

Hudaya, Kharisman Kholid. 2015. Cara Cepat Menguasai Java Desktop dengan Metode Pro-OOP. Yogyakarta: Andi.

[7] Riestiana, Meita dan Sukadi. 2014. Sistem Informasi Penggajian Karyawan Pada Commenditaire Vennontschap (CV) Bordir Dan Konveksi Pacitan. Journal Speed Sentra Penelitian Engineering dan Edukasi. Vol.6. No.4.

[8] Hartono, Jogiyanto. 2005. Analisis dan Desain. Yogyakarta: Andi Offset
[9] Simarmata, Janner dan Paryudi Imam. 2010. Basis Data. Yogyakarta: Andi Offset 